\title{
Development of a generator to power ATP-driven molecular motors.
}

\author{
Final Report \\ DOE Grant \#DE-FG 02-99ER14967 \\ Carlo Montemagno, Ph.D. \\ Cornell University
}

\section{EXPERIMENTAL RESULTS}

\section{Purification of enzymes.}

We were unable to obtain reconstitutionally active $T F_{1} F_{0}$ using the method of Kagawa and Sone (1979), and developed an improved purification protocol for this enzyme that utilizes the detergent $n$-Dodecyl ${ }_{\beta}-\mathrm{D}-$ Maltoside (Hazard et. al, manuscript in preparation). Bacteriorhodopsin was purified using the method of Dencher and Heyn (1982).

\section{Preparation of proteolipsomes.}

Liposomes were prepared by sonicating lipid/cholesterol mixtures in 3:1 diethyl ether: aqueous buffer; removing organic solvent by rotary evaporation; and filtering liposomes successively through 0.45 and $0.22 \mu \mathrm{m}$ filters (Richard et al., 1995; Rigaud et al., 1983; Szoka and Papahadjopoulos, 1978). The final composition of liposomes was $20 \mathrm{mM}$ lipid (9:1 phosphatidyl choline: phosphatidic acid), $6 \mathrm{mM}$ cholesterol. This composition was chosen as it has been shown to optimize $\mathrm{TF}_{1} \mathrm{~F}_{0}$ ATP synthesis activity (Pitard et al., 1996, Eur J Biochem. 235, 769).

Proteoliposomes were formed by protocol adapted from Sone et al. (1975). Briefly, $\mathrm{TF}_{1} \mathrm{~F}_{0}$, bacteriorhodopsin, and liposomes were solubilized in a solution containing $20 \mathrm{mM}$ cholate, 10 $\mathrm{mM}$ deoxycholate. Pyranine $(200 \mu \mathrm{M})$ was included as desired for measurement of internal $\mathrm{pH}$. Samples were diluted fourfold with Dialysis Buffer (20 mM MOPS, $50 \mathrm{mM} \mathrm{Na} \mathrm{SO}_{4}, 50 \mathrm{mM}$ $\mathrm{K}_{2} \mathrm{SO}_{4}, 2.5 \mathrm{mM} \mathrm{MgSO}{ }_{4}, 0.25 \mathrm{mM}$ DTT, $0.2 \mathrm{mM}$ EDTA), and dialyzed overnight at $4^{\circ} \mathrm{C}$ against three changes of the same buffer. Samples stored at $4^{\circ} \mathrm{C}$, and retained activity for up to two weeks.

\section{Measurement of pH gradient formation.}

Change in internal $\mathrm{pH}$ was determined using pyranine fluorescence as previously described (Overly et al., 1995; Pitard et al., 1996). Light-dependent $\mathrm{pH}$ gradient formation by bacteriorhodopsin was activated using an Intralux xenon lamp fitted with a yellow filter, and ATP-dependent $\mathrm{pH}$ gradient formation by $\mathrm{TF}_{1} \mathrm{~F}_{0}$ was initiated by the addition of $15 \mathrm{mM} \mathrm{MgATP}$. Figure 1 illustrates typical data for bacteriorhodopsin (closed circles) and $\mathrm{TF}_{1} \mathrm{~F}_{0}$ (open circles). Bacteriorhodopsin typically produced a maximum $\mathrm{pH}$ gradient of $\sim 1$ unit, while $\mathrm{TF}_{1} \mathrm{~F}_{0}$ produced a $\mathrm{pH}$ gradient of $\sim 0.5$ units. For bacteriorhodopsin- $\mathrm{TF}_{1} \mathrm{~F}_{0}$ proteoliposomes, a light-driven $\mathrm{pH}$ gradient was maintained for at least 30 minutes dark incubation, indicating that proteoliposomes are adequately proton-impermeable. Both light- and ATP-dependent $\mathrm{pH}$ gradient formation were reversed by the addition of the uncoupler CCCP, and ATP-dependent $\mathrm{pH}$ gradient formation was inhibited by the $\mathrm{F}_{0}$-inhibitor DCCD (data not shown).

DOE Patent Clearance Granted

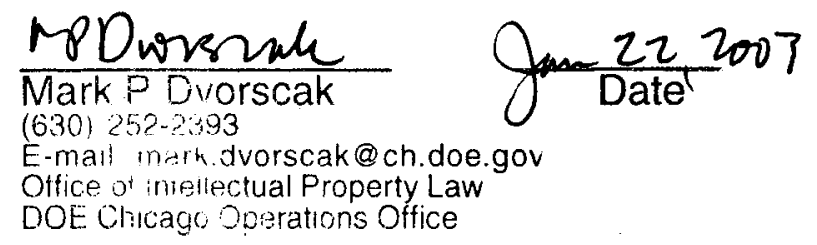




\section{DISCLAIMER}

This report was prepared as an account of work sponsored by an agency of the United States Government. Neither the United States Government nor any agency Thereof, nor any of their employees, makes any warranty, express or implied, or assumes any legal liability or responsibility for the accuracy, completeness, or usefulness of any information, apparatus, product, or process disclosed, or represents that its use would not infringe privately owned rights. Reference herein to any specific commercial product, process, or service by trade name, trademark, manufacturer, or otherwise does not necessarily constitute or imply its endorsement, recommendation, or favoring by the United States Government or any agency thereof. The views and opinions of authors expressed herein do not necessarily state or reflect those of the United States Government or any agency thereof. 


\section{DISCLAIMER}

Portions of this document may be illegible in electronic image products. Images are produced from the best available original document. 


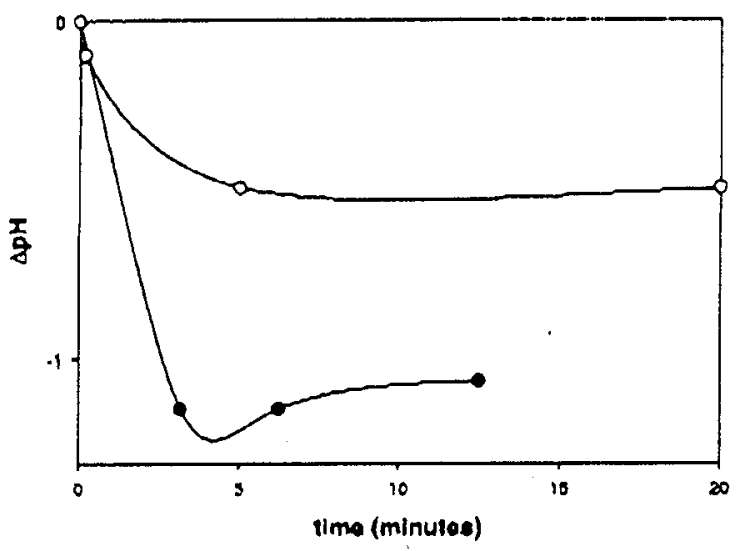

Figure 1. Closed circles- Light-driven $\mathrm{pH}$ gradient formation by bacteriorhodopsin; sample contained $20 \mu \mathrm{g} / \mathrm{ml} \mathrm{TF} F_{0}, 138 \mu \mathrm{g} / \mathrm{ml}$ bacteriorhodopsin, $3.3 \mathrm{mM}$ liposome. A maximum $\Delta \mathrm{pH}$ of 1.1 unit was reached within 3 minutes. Open circles- ATP-driven $\mathrm{pH}$ gradient formation by $\mathrm{TF}_{1} \mathrm{~F}_{0}$. Sample contained $0.02 \mu \mathrm{g} / \mathrm{ml} \mathrm{TF}_{1} \mathrm{~F}_{0}$ and $3.3 \mathrm{mM}$ lipsome. To ensure that no light-driven proton pumping could occur, no bacteriorhodopsin was present. A maximum $\triangle \mathrm{pH}$ of 0.7 units was reached within 5 minutes.

\section{Measurement of ATP synthesis activity.}

Bacteriorhodopsin and $\mathrm{TF}_{1} \mathrm{~F}_{0}$ were reconstitured into proteoliposomes as described above. Samples were illuminated for five minutes to obtain a maximum $\mathrm{pH}$ gradient, at which point the ATP synthesis reaction was initiated by the addition of $4 \mathrm{mM} \mathrm{Mg}$-ADP, $20 \mathrm{mM}$ Pi. Aliquots were removed at the indicated times, and the reaction stopped by the addition of $2 \%$ TCA. ATP was quantified using the luciferin/luciferase assay kit from Sigma (Sigma \#FL-AA). A typical ATP synthesis reaction is illustrated in Figure 2. Curiously, the ATP synthesis rate increases with time up to sixty minutes. This rate increase is does not appear to be related to an increase in the $\mathrm{pH}$ gradient, as ATP synthesis was not initiated until the $\mathrm{pH}$ gradient was at a maximum. To test the possibility that substrate binding causes a slow activation of the enzyme, samples were preincubated with $\mathrm{Mg}-\mathrm{ADP}$ or with Pi for 30 minutes prior to initiation of the ATP synthesis reaction; the results obtained were identical whether or not proteoliposomes were preincubated with either substrate. Richard et al. observed a similar increase in ATP synthesis rate for $\mathrm{TF}_{1} \mathrm{~F}_{0}$, which was unaffected by the duration of light-preincubation, or by preincubation with substrates (1995). These results suggest that $T F_{1} F_{0}$ is slowly activated by enzymatic tumover. By contrast, the same authors observed that the chloroplast $F_{1} F_{0}$ ATP synthesis rate remained unchanged over time. 


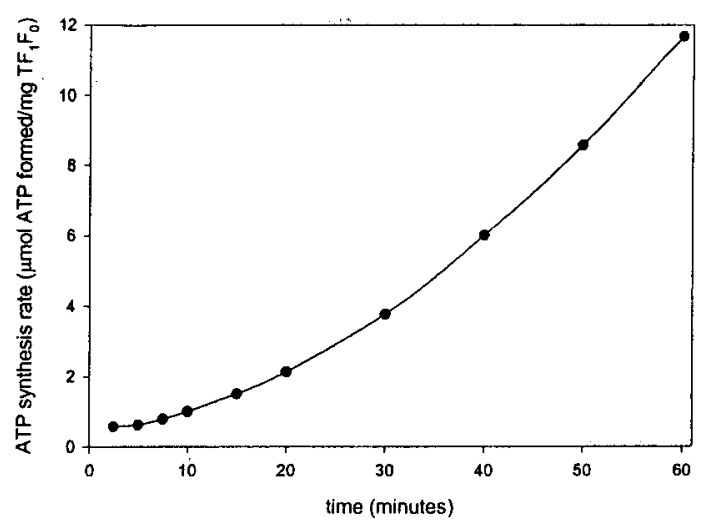

Figure 2. Typical ATP synthesis reaction. Sample contained $30 \mu \mathrm{g} / \mathrm{ml} \mathrm{TF}_{1} \mathrm{~F}_{0}, 413 \mu \mathrm{g} / \mathrm{ml}$ bacteriorhodopsin, $5 \mathrm{mM}$ liposome. Experiments were done at $30^{\circ} \mathrm{C}$. Similar results were obtained for experiments done at 25 and $42^{\circ} \mathrm{C}$ (data not shown). Data represent an average of three measurements.

As the ATP synthesis rate changes with time, it is necessary to indicate at what time point activity was measured. At sixty minutes, the sample shown in Figure 2 had an activity of 193 $\mathrm{nmol} / \mathrm{min} / \mathrm{mg}$. The composition of proteoliposomes in this sample was $30 \mu \mathrm{g} / \mathrm{ml} \mathrm{TF}_{1} \mathrm{~F}_{0}, 413$ $\mu \mathrm{g} / \mathrm{ml}$ bacteriorhodopsin, $5 \mathrm{mM}$ lipid. Similar activities were obtained when the bacteriorhodopsin concentration was varied between 138 and $600 \mu \mathrm{g} / \mathrm{ml}$ at a set $\mathrm{TF}_{1} \mathrm{~F}_{0}$ concentration, or when the $\mathrm{TF}_{1} \mathrm{~F}_{0}$ concentration was varied between $20-60 \mu \mathrm{g} / \mathrm{ml}$ at a set bacteriorodopsin concentration. Furthermore, the magnitude of the $\mathrm{pH}$ gradient was unaffected by the initiation of ATP synthesis. These results indicate that, within the $\mathrm{TF}_{1} \mathrm{~F}_{0}$ concentration range tested, ATP synthesis is not being limited by bacteriorhodopsin concentration. Thus, the observed ATP synthesis rate presumably represents the maximum achievable rate for $\mathrm{TF}_{1} \mathrm{~F}_{0}$ under the experimental conditions tested.

\section{SUMMARY}

Here, we report a maximum ATP synthesis rate of $193 \mathrm{nmol} / \mathrm{min} / \mathrm{mg}$ for thermophilic $F_{1} F_{0}$. This rate is somewhat lower than the previously observed maximum rate of $500-700 \mathrm{nmol} / \mathrm{min} / \mathrm{mg}$ (Pitard et al., 1996). However, ATP synthesis rates vary considerably with experimental conditions, and our observed rates compare favorably with the wide range of rates (40-700 $\mathrm{nmol} / \mathrm{min} / \mathrm{mg}$ ) observed by these authors. Future research will focus on maximizing the ATP synthesis rate by adjusting environmental conditions, including the lipid and cholesterol composition of the proteoliposomes.

\section{REFERENCES}

Dencher, N.A. and Heyn, M.P. 1982. Meth. Enzymol. 88, 5-10.

Kagawa, Y. and Sone, N. 1979. Meth. Enzymol. 55, 364-373.

Overly, C.C., Lee, K-D., Berthiaume, E., and Hollenbeck, P.J. 1995. PNAS 92, 3156-3160.

Pitard, B., Richard, P., Dunach, M., Girault, G., and Rigaud, J.L. 1996. Eur. J. Biochem. 235, 769-778. 
Richard, P., Pitard, B., and Rigaud, J.-L. 1995. J. Biol. Chem. 270, 21571-21578.

Rigaud, J.L., Bluzat, A., and Buschlen, S. 1983. BBRC 111, 373-382.

Sone, N., Yoshida, M., Hirata, H., Kagawa, Y. 1975. J. Biol. Chem. 250, 7917-7923.

Szoka, F. and Papahadjopoulos, D. 1978. PNAS 75, 4195-4198. 